\title{
Flood risk management in the Souss watershed
}

\author{
Brahim Bouaakkaz ${ }^{1 *}$, Zine El Abidine El Morjani ${ }^{1}$, Lhoussaine Bouchaou ${ }^{2}$, and Hamza \\ Elhimri $^{3}$ \\ 1: Exploration and Management of Natural and Environmental Resources Team (EGERNE), \\ Polydisciplinary Faculty of Taroudant (PFT), University Ibn Zohr, Morocco \\ 2: Applied Geology and Geo-Environment Laboratory, Ibn Zohr University, Faculty of Science, \\ Agadir, Morocco \\ 3: Souss Massa Hydraulic Basin Agency, Av Prince My Abdellah, New Town, BP 432, Agadir, \\ Morocco
}

\begin{abstract}
Flooding is the most devasting natural hazards that causes more damage throughout the world. In 2016, for the fourth year in a row, it was the most costly natural disaster, in terms of global economic losses: $\$ 62$ billion, according to a Benfield's 2016 annual report on climate and natural disasters [1]. The semi-arid to arid Souss watershed is vulnerable to floods, whose the intensity is becoming increasingly alarming and this area does not escape to the effects of this extreme event.. Indeed, the susceptibility of this region to this type of hazard is accentuated by its rapid evolution in terms of demography, uncontrolled land use, anthropogenic actions (uncontrolled urbanization, encroachment of the hydraulic public domain, overgrazing, clearing and deforestation). ), and physical behavior of the environment (higher slope, impermeable rocks, etc.). It is in this context, that we have developed a strategic plan of action to manage this risk in the Souss basin in order to reduce the human, economic and environmental losses, after the modeling of the flood hazard in the study area, using georeferenced information systems (GIS), satellite remote sensing space and multi-criteria analysis techniques, as well as the history of major floods. This study, which generated the high resolution $30 \mathrm{~m}$ flood hazard spatial distribution map of with accuracy of $85 \%$, represents a decision tool to identify and prioririze area with high probability of hazard occurrence. It can also serve as a basis for urban evacuation plans for anticipating and preventing flood risk in the region, in order to ovoid any dramatic disaster.
\end{abstract}

Keywords: Flood, Disaster, Hazard, Vulnerability, Risk, Climate Change, GIS, Remote Sensing, Strategic Action Plan, Multicriteria Analysis, Watershed, Souss, Morocco.

*Corresponding author: bouaakkaz2012@gmail.com 


\section{Introduction}

The study area (Souss River Basin) covers approximately17000 km2, in the Souss Massa, Draa tafilalt and Marrakech tensift regions, includes 128 territorials community (fig.1). It is limited by the southern mountain of the Western High Atlas, the northern mountain of the Western Anti Atlas, the Siroua massif in the east and by the Atlantic Ocean in the west. Thus, it is situated in south-west Morocco, between 29th and 31st parallels north, and between 7th and 10th degree west longitude of Greenwich [2]. Whose economic activity is mainly based on fishing, tourism, and farming (especially, vegetables, fruits and bouquets).

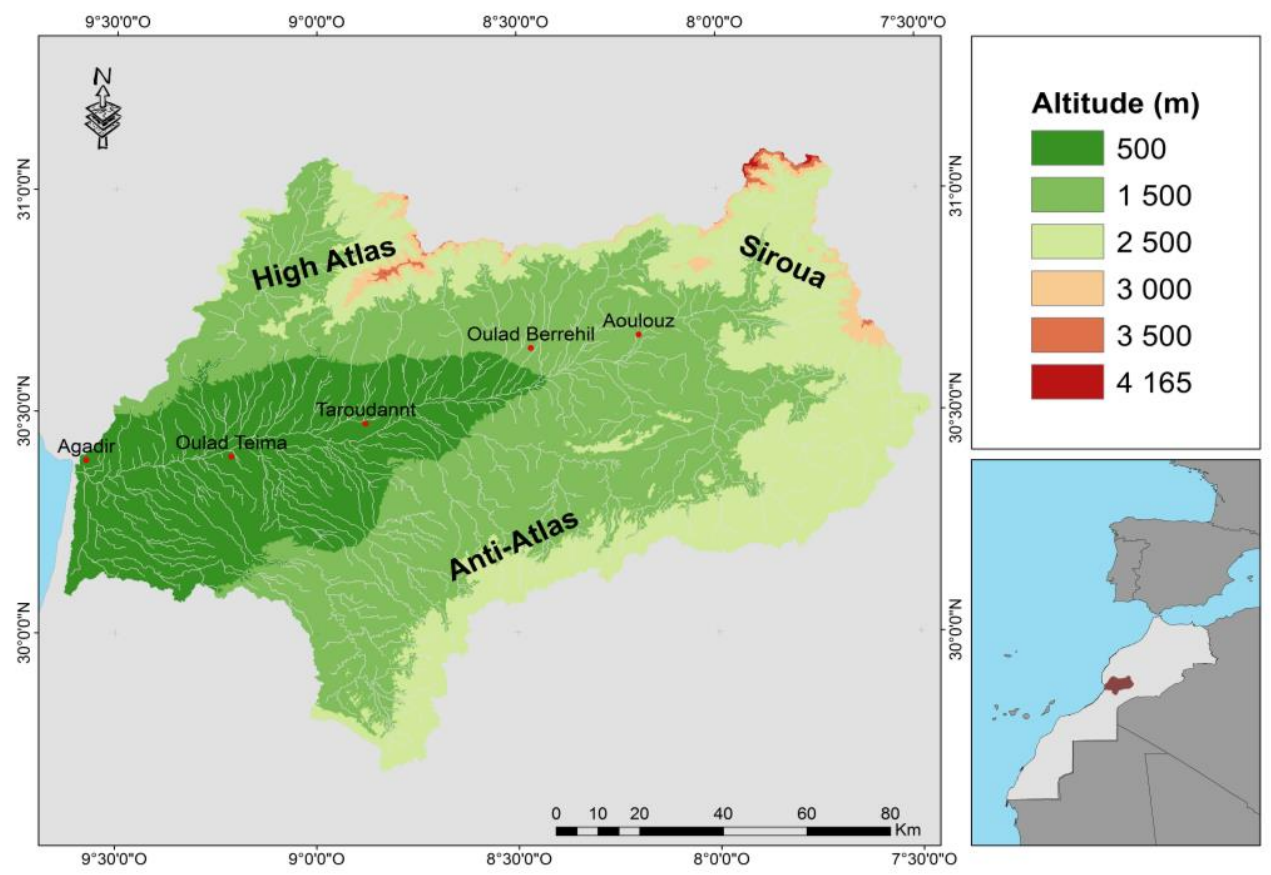

Fig. 1. Location map of the Souss watershed.

Precipitation modules exceed, in a short time, the totals typical of these regions in a normal year $[2,3]$.

Therefore flood hazard is a phenomena that can turn into a disaster as has been repeatedly demonstrated and is a challenge for sustainable development. Climate change will amplify existing risks and generate new ones for natural and human systems $[4,5]$. Thus, the frequent overflows of Souss river (main collector of the basin) and its tributaries have caused, on several occasions, material, environmental, social and economic important damage, in particular during passage of the exceptional floods of February, November 2010 and 2014 (fig.2).

The study area was selected for its importance in the context of the regional economy and for the presence of rapidly developing anthropization, anarchic urbanization and land cover conversion dynamics; such land changes also make the territory especially vulnerable to climate change-induced flood hazard. 



Fig. 2.Urban flood in Agadir city, February 2010 (ABHSMD Photo, 2010)

Although the Moroccan authority has each time made progress in the system of actions for the prevention of natural disasters (National strategy for the protection of the environment and sustainable development, water resources management strategy, national plan update study). [6], etc.), this progress was considered very modest, notably by the Hyogo Framework for Action [7]. In addition, there is no insurance system to provide financial protection against the risk of flooding [7] and there is a lack of a framework law on risk prevention. For this purpose, the damage is heavy to manage in the absence of insurance coverage.

Among the objectives of this work is the strengthening of communities' knowledge and capacities to deal with natural hazards, with a view to improving prevention systems and protection in crisis management situations. Since our society has no choice but to face this meta-risk [8] because it is an integral part of our environment.

\section{Materials and methods}

In this context, the determination of the areas likely to be affected flooding is essential for better management of this risk. The method adopted in this paper associates a triple approach of geomatic (remote sensing with GIS) and field, as well as the statistical treatment of data collected from the Souss Massa Hydraulic Basin Agency (ABHSMD) of the rainfall of the hydrological stations and the Frequency analysis of peak flows of Souss River.

\subsection{Methodology for generating the spatial distribution of the intensity levels of flood hazard}

The process used to spatially distribute flood hazard combines the extent of past flood events with the spatial distribution of causal factors influencing the flood hazard $[9,10,11$, 12], by using the Remote Sensing technique and Geographic Information Systems, as well as multicriterate analysis techniques. This combination enables the calculation of a weighted score for each individual causal factor. The spatial distribution of the weighted scores are then aggregated to derive the distribution of the flood hazard index (FHI) before being reclassified to obtain the spatial distribution of the intensity level of flood hazard.

The application of this method requires the execution of the following steps to generate the spatial distribution flood hazard map figure 4:

- Identification and generating of the causal factors at $30 \mathrm{~m}$ resolution ( Digital Elevation Model (DEM); Slope, Aspect, flow accumulation, land cover, lithology, soil type, precipitations, $[9,10]$; 
- Creation and classification of the historical number of past flood events distribution map;

- Estimation of the weight of each factor (weighting);

- Standardization of factors (SWS) ;

- Production the spatial distribution map of the flood hazard index;

- Reclassification of the map generated according to five intensities of the flood hazard (very low, low, medium, high and very high) as final result (Fig.4).

- Validation of the flood hazard distribution map resulted by the Souss Massa Hydraulic Basin Agency data

For more details concerning the methodology used to generate the spatial distribution of the intensity levels of flood hazard, please refer to the [9] publication.

\subsection{Frequency analysis of the peak flows of the wadi Souss}

Frequency analysis of a long series of historical maximum flows (Fig.3) by the adjustment of Gumbel's law makes it possible to estimate the return time of a particular value, thus to predict the probability of occurrence of future floods, in order to anticipate the occurrence of a flood, and to alert the populations. Since risk management requires first and foremost a fair assessment of existing risks, their spatialization as well as their probability of occurrence [13].

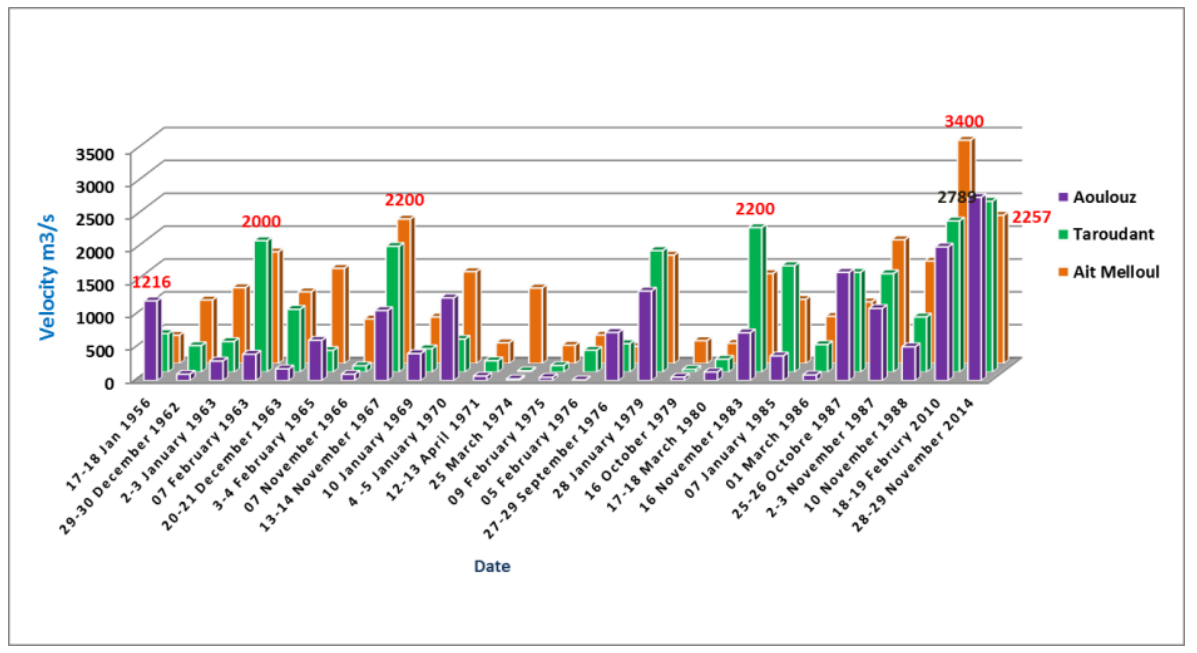

Fig. 3. Flood history of the Souss River at the stations of Aoulouz, Taroudant and Ait Mellou 


\subsection{Field investigation, diagnosis of the inventory and analysis of the legal framework for flood management}

In addition, this method includes, exploration of the terrain through visits to vulnerable sites that can locate problems and also meet the flood victims who are the object of study and make the findings finally which are necessary. Since the increased involvement of the local populations should become essential and become obvious to improve flood risk management. As well as, the study of the different Legislative text and components of the flood risk management framework. Finally, the analytical and critical study of measures, flood protection works and direct and indirect development projects carried out by the various actors, namely: Prediction, prevention and the alert process.

\section{Results and discussion}

\subsection{Spatial distribution of the flood hazard in the study area}

The examination of the flood hazard map (Fig.4) shows that the level of flooding is very high both in the High Atlas and Siroua regions. This is due to lithology characteristics (impermeable rocks: marls, shales and crystalline rocks), highly slopes and significant annual rainfall in those areas (greater than $500 \mathrm{~mm} /$ year [2]). However, the level of hazard is very low in the Anti-Atlas. This is explained by the dominance of permeable limestone formations in this chain which receives only 150 to $200 \mathrm{~mm}$ as annual average precipitation.

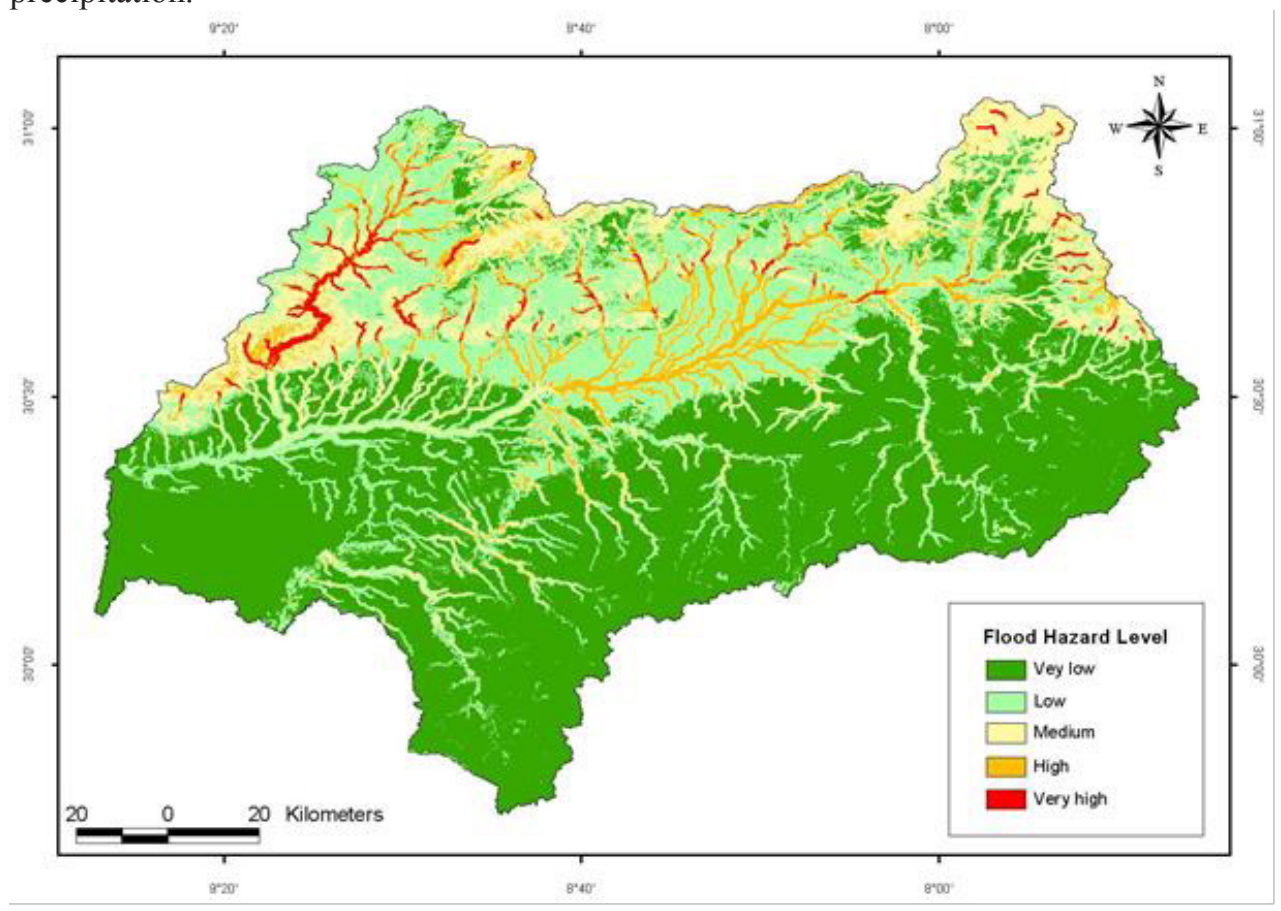

Fig. 4. Flood hazard distribution map for the Souss river basin (with a resolution of 30m) [9]. 


\subsection{Frequency analysis of the peak flows of the Souss River}

Frequency analysis of a long series of maximum flows allows to estimate the return time of a particular value. The adjustment of Gumbel's law to the floods of Souss River showed a satisfactory adequacy (Fig.5). This law describes the probability of occurrence of floods and their periods of return. Floods with a peak of at least $300 \mathrm{~m}^{3} / \mathrm{s}$ (which is already 54 times the Aoulouz module) occur on average every year, and even floods greater than 1000 $\mathrm{m}^{3} / \mathrm{s}$ occur every five to ten years at Ait Melloul, while those higher than $2000 \mathrm{~m}^{3} / \mathrm{s}$ and $3000 \mathrm{~m}^{3} / \mathrm{s}$ are respectively fifty-year and centennial floods. This relatively high frequency of floods is probably explained by the very large area drained by Wadi Souss and its many tributaries $\left(17000 \mathrm{~km}^{2}\right)$, and the low permeability of the slopes of High Atlas, which may offer response times to rather short showers

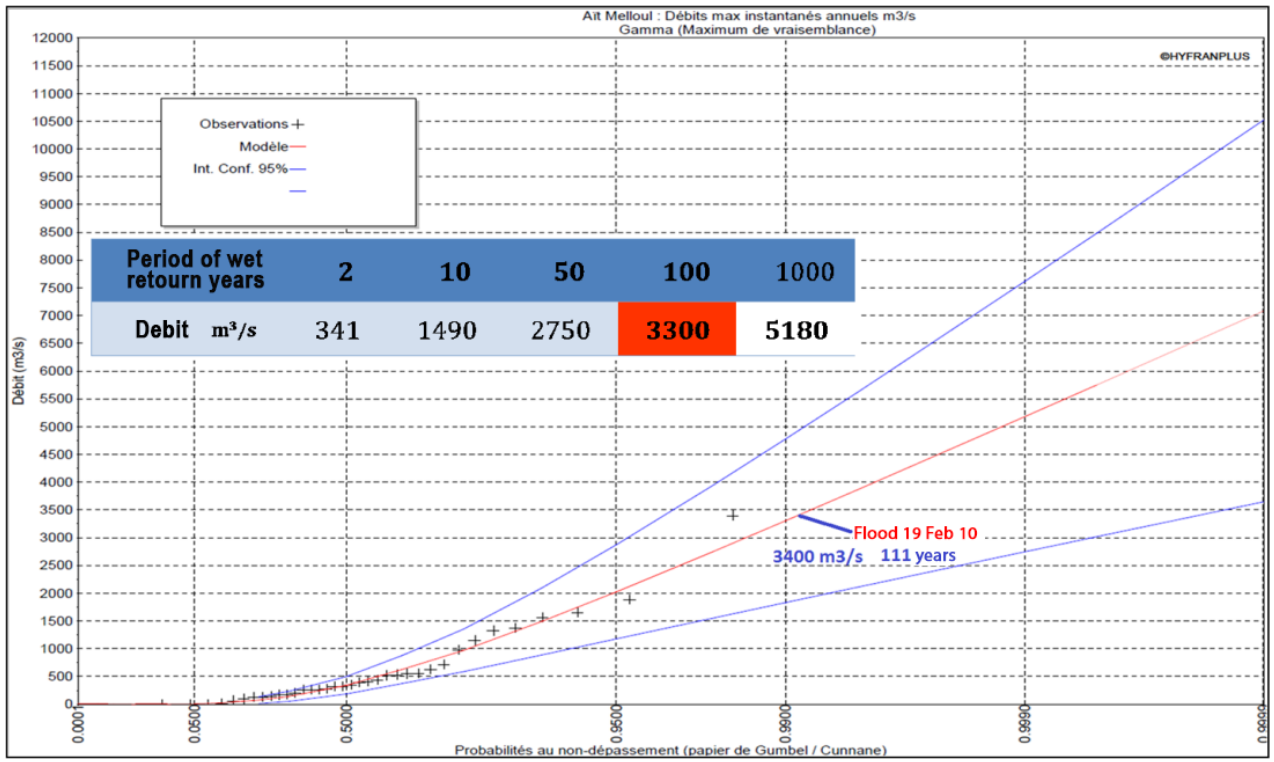

Fig. 5. Gumbel Adjustment with the floods of Souss River, at the ait Melloul station

\subsection{Field investigation, diagnosis of the inventory and analysis of the legal framework for flood management}

An analysis of the current situation shows that all the actors (the State, ABHSM, Council of the Region, Provincial Council) have made efforts to fight against the risk of flooding in the basin in question, but remains insufficient for the sustainable and integrated management of this risk.

Indeed, the implementation of the national strategy for sustainable development, which runs from 2015 to 2020, already developed (takes into account protection against floods) has not yet come into force.

In addition, there is a delay in the implementation of the National Program for Rural Sanitation (PNAR) and the sanitation networks in the sanitation centers have lower evacuation capacity, it happens that networks overflow before the waters reach the outlets (case of the Agadir city in February 2010.Photo.1). 
As a result, the risk of storm and urban flooding is a potential hazard and necessitates upgrading of the sewerage network, in order to increase its drainage capacity due to climate change in the region.

The study of the various legislative and regulatory texts of the flood risk management framework indicates that several entanglements of skills exist because of the multiplicity of public actors and the absence of a strategy dedicated to the protection against this extreme phenomenon. The Water Act 36-15 has given diversified allocations to basin agencies including ABHSM. This multiplicity of tasks has not resulted in sufficient human and financial resources, which delays the advancement of flood risk protection work to protect the vulnerable population.

Indeed, according to the master plan study of flood protection in the province of Taroudant ( $97 \%$ of the basin area), the financial cost of the projects of protection against this risk is of the order of 400 Millions of dirhams. This requires the urgent intervention of all actors to treat vulnerable sites and carry out structural protection works (dams, dikes, flow diversion, etc.) in a timely manner to avoid the aggravation of the situation following the changes climate.

The analysis of the water law of 36-15 published in the official bulletin $n^{\circ} 6506$ of 6 October 2016 in terms of protection against floods attaches' importance to the fight against this risk of flooding. Three sub-sections of 7 articles of this legislation deal exclusively with the protection and prevention of risk, detection, monitoring and warning devices, as well as the management of flood events (Articles 117 to 123).

Nevertheless, the current institutional framework does not favor the implementation of planned actions of protection against floods. Indeed, there is a lack of regulatory and legislative framework governing the management of flood risk marked by a lack of implementing legislation for the Water Law 36-15, an absence of regulations applicable to floodplains and the risk of flooding is not integrated in urban planning documents.

On the other hand, the law 30-15 on the safety of the dams for the protection of the downstream populations is not applicable for the reinforcement of the legal arsenal in this field. Its implementation requires obligations to continue to upgrade dams, including compliance with safety standards, in order to protect as much as possible the risks of breakage or failure. In 2013, the water department updated the study of the National Flood Protection Plan (NFPP) [6] in order to draw up the state of progress of the treatment of vulnerable sites and to update data and information concerning the priority sites. However, the financial resources mobilized are also limited compared to the means provided to cover the components of the NFPP.

The latter focused on the treatment of blackheads resulting from floods, regardless of the causes and degrees of flood exposure. As a result, the approach advocated by the NFPP has meant that the protection actions undertaken in this context are often carried out piecemeal in the absence of a broader strategy for the prevention and protection of vulnerable areas.

The follow-up of the last floods that occurred in the region in February and November 2010 and 2014 revealed the unsuitable dimensioning of the crossing structures and the inadequacy of certain bridges and crossing works along roads intersecting the courses of water. These structures are impediments to flow and contribute to the raising of water levels and overflowing.

In addition, the insufficient mastery of the hydraulic public domain (HPD), which has not been defined, does not allow the ABHSM to respond to requests from stakeholders 
in this field (urban agencies, local authorities, etc.). What hampers the rigorous enforcement of flood-zone construction regulations and the policing role of water remains very limited in time and space.

Examination of the spatial distribution of the hydro-climatological network, shows that it is less developed on the basin on the left bank of the Souss River, its density is low (15 stations rainfall) and not automated. Indeed, the Anti-Atlas is not covered by hydrological stations, especially in the areas of high vulnerability to flooding namely wadis Arghene, Tiout and Aourgua.

In addition, high-frequency shift data transmission systems are nowadays little adapted to the needs of real-time knowledge of phenomena. In fact, this system is very often disturbed during periods of bad weather and night shift.

In this context, and in order to be able to improve the protection of people and property against floods in the study area, several technical, organizational and financial actions must be put in place to increase the resilience of the exposed territory and reduce vulnerability against this risk.

Therefore, it is desirable to promote integrated flood risk management based on three pillars: I. Prevent and develop, II. Prepare, manage the crisis and III. Act after the crisis.

Feedback is also crucial, as the information gained through this type of event must be capitalized in order to be reused in forecasting models and prevention actions.

In addition to carrying out palliative work to protect vulnerable sites, the proposed action plan provides the implementation of structural and non-structural actions based on the following main provisions (Table 1):

Table 1. Structural and non-structural measures of flood risk management

\begin{tabular}{|l|l|}
\hline \multicolumn{1}{|c|}{ Non-structural measures } & \multicolumn{1}{|c|}{ Structural measures } \\
\hline $\begin{array}{l}\text { Strengthening meteorological and hydrological } \\
\text { watch and creating refuge areas and evacuation traps } \\
\text { in the most exposed areas; }\end{array}$ & $\begin{array}{l}\text { Continued development of dams and hill } \\
\text { lakes, which studies have already been } \\
\text { finished and inventories of other potential } \\
\text { sites for flood rolling; }\end{array}$ \\
\hline $\begin{array}{l}\text { Implementation of a flood forecasting and warning } \\
\text { system and the automation of hydrological } \\
\text { observation (rain and water level) in some flood } \\
\text { warning stations and vulnerable wadis devoid of } \\
\text { dams (Irguiten wadis, Tiout, Assads and Aghren). } \\
\text { The implementation of the identification markers of } \\
\text { the sectors at risk of flooding; }\end{array}$ & $\begin{array}{l}\text { implements monitoring, maintenance and } \\
\text { management measures to ensure the safety of } \\
\text { residents downstream; }\end{array}$ \\
\hline $\begin{array}{l}\text { The reform of the legislative framework governing } \\
\text { the flood risk management and setting up of a } \\
\text { platform for exchange between all the stakeholders } \\
\text { in this area to initiate the necessary political } \\
\text { orientations in this field; }\end{array}$ & $\begin{array}{l}\text { Watershed development through the } \\
\text { construction of thresholds, the construction of } \\
\text { dry stone terraces and reforestation with } \\
\text { adaptive plants by the direction of water and } \\
\text { forest to increase infiltration at the expense of } \\
\text { runoff and reduce the rate of siltation in dams; }\end{array}$ \\
\hline $\begin{array}{l}\text { The updating of the delimitation of flood risk areas } \\
\text { at territorial community level (Atlas of regions } \\
\text { threatened with flooding), to inform the population } \\
\text { of the risks to which they are exposed; }\end{array}$ & $\begin{array}{l}\text { Reservation of a hollow volume to absorb the } \\
\text { floods at the levels of dam reservoirs and } \\
\text { mitigate the brutal pulsations of the main } \\
\text { collector (Souss river); }\end{array}$ \\
\hline $\begin{array}{l}\text { Development of the awareness of the populations to } \\
\text { risk by the sensitization, the development of the }\end{array}$ & $\begin{array}{l}\text { Development of water diversion structures } \\
\text { and flood protection dams in upstream; }\end{array}$ \\
\hline
\end{tabular}




\begin{tabular}{|c|c|}
\hline $\begin{array}{l}\text { memory of the risk and the diffusion of the } \\
\text { information; }\end{array}$ & \\
\hline $\begin{array}{l}\text { The updating of land-use planning documents to } \\
\text { control the use of areas in risk of flooding; }\end{array}$ & $\begin{array}{l}\text { Study the possibility of raising the height of } \\
\text { dams in operation, to composite the rate of } \\
\text { siltation and to reduce the floods; }\end{array}$ \\
\hline $\begin{array}{l}\text { The development and strengthening of financial } \\
\text { mechanisms (insurance and disaster funds), } \\
\text { consultation and coordination between different } \\
\text { actors; }\end{array}$ & $\begin{array}{l}\text { Cleaning and recalibration of the sections of } \\
\text { wadis filled by erosion deposits, to increase } \\
\text { flow and avoid overflow; }\end{array}$ \\
\hline $\begin{array}{l}\text { Perform technology transfer through the training of } \\
\text { flood risk management personnel of the various } \\
\text { actors. }\end{array}$ & $\begin{array}{l}\text { Update studies and analyzes of all aspects } \\
\text { related to the phenomena of floods: Climate, } \\
\text { hydrology, flow, topography, morphology, } \\
\text { geology, geomorphology, and hydraulics } \\
\text { aspects to determine the thresholds of } \\
\text { warning in case of extreme precipitation and } \\
\text { flows. }\end{array}$ \\
\hline
\end{tabular}

To identify this problem in its entirety, the establishment of real sustainable financing is a crucial element to the success of any program and action plans of intervention works to increase capacity and reduce the vulnerability of local residents. It is desirable to set up a joint flood commission which will be a place for dialogue and exchange between the various actors involved in flood prevention (water management, urban planning, etc.)

\section{Conclusions and recommendations}

The map of the spatial distribution of the flood hazard with a high resolution of $30 \mathrm{~m}$, and accuracy $85 \%$ is a tool to identify areas where decision makers can intervene. As it can serve as a basis for urban evacuation, anticipation and prevention plans in case of flood risk.

By studying the peaks of various floods calculated in the Souss valley since 1956, only those of February 2010 and November 2014 are the most devastating. The precipitation that triggered these catastrophic floods have largely exceeded, in a short time, the typical totals of these regions during a normal year.

This methodological process could be transferred and implemented in other basins or regions of Morocco by exploiting their own precise and reliable data and information. In order to study the risk of flooding in a global and integrated ways, the field opens up innovative perspectives for the future use of the very high resolution models and the assessment of social and economic vulnerability within this extreme event environment. The knowledge of the various aspects constituting the vulnerabilities of a territory subject to flood risk represents an important contribution to reduce and control the consequences on already existing sensitive equipment.

This study also demonstrated the need to improve the institutional framework for climate change, including flood prevention and control through the introduction of a compensation system. In addition, updating the laws governing the management of this risk and their applications is desirable.

In order to prevent the damage of future floods, the mapping of the dynamic evolution of this risk, is desirable by means of radar remote sensing which ensures at all times the availability of the information despite the meteorological conditions.

Finally, promote research, innovation and technology transfer in the field of adaptation to climate change, specially the risk of flooding. 


\section{Acknowledgments}

We would like to thanks the Souss-Massa Hydraulic Basin Agency (ABHSM) for providing us with the complete database needed for this study.

\section{References}

1. A. Benfield (2016). Analytics Impact Forecasting : Annual Global Climate and Catastrophe Report. $73 \mathrm{p}$;

2. B. Bouaakkaz (2015). Le bassin versant de l'oued Souss : caractéristiques physiques, climatiques et comportement hydrologique : prospectives territoriales, «Mémoire d'accomplissement des modules du master spécialisé : Aménagement, Développement, Gestion et Prospectives territoriales dans les zones arides et semi-arides ». Université Ibn Zohr, Agadir. 137 p.

3. L. Chakir, A. Aït Hssaïne, B. Bouaakkaz (2015). Les crues de l'oued Souss et le risque de l'inondation dans le tronçon aval de la vallée (Maroc), Laboratoire: Géoenvironnement et développement des zones arides et semi-arides (GEDEZA) Département de géographie, Université Ibn Zohr, B.P. 29/S, Agadir, Maroc.

4. GIEC, (2014). Changements climatiques 2014: «Rapport de synthèse» : Contribution des Groupes de travail I, II et III au cinquième Rapport d'évaluation du Groupe d'experts intergouvernemental sur l'évolution du climat.GIEC, Genève, Suisse, $161 \mathrm{p}$

5. S. Rannow, M. Neubert (Eds.). (2014). Managing protected areas in central and eastern Europe under climate change. Springer, 322p.

6. Royaume Du Maroc, Ministère Délégué Auprès Du Ministre De L'énergie, Des Mines, De L'eau Et De L'environnement, Charge de L'eau (2013). Étude d'actualisation du plan national de protection contre les inondations, Sous-Mission I-1 : «Rapport d'Analyse des études et travaux de protection réalisés pour la lutte contre les inondations».112p

7. Département De L'environnement Du Ministère De L'énergie, Des Mines, De L'eau Et De L'environnement (2013). Rapport national de suivi sur la mise en cuvre du Cadre d'action de Hyogo «Rapport d'évaluation»,41p

8. E. Rioust (2013). Gouverner l'incertain : adaptation, résilience et évolutions dans la gestion du risque d'inondation urbaine : les services d'assainissement de la Seine-Saint-Denis et du Val-deMarne face au changement climatique. "Thèse en Architecture, aménagement de l'espace». Université Paris-Est, 429p

9. Z.E.A. El Morjani, M. Seif Ennasr, A. Elmouden, S. Idbraim, B. Bouaakaz, Et A. Saad (2016). Flood Hazard Mapping and Modelling using GIS applied to the Souss River watershed. R. ChoukrAllah et al. (eds.), the Souss-Massa River Basin, Morocco. "Chapter part of the series The Handbook of Environmental Chemistry pp 1-30», DOI 10.1007/698_2016, Springer International Publishing Switzerland

10. Z.E.A. El Morjani, (2011a). «Preparation of the dataset. Methodology document for the WHO eatlas of disaster risk. Volume 1. Exposure to natural hazards. Version 2.0». Taroudant polydisciplinary faculty of the Ibn Zohr University of Agadir, Morocco. ISBN: 978-9954-0-5397-3.

11. Z.E.A. El Morjani, (2011b). Methodology document for the WHO e-atlas of disaster risk. "Volume 1. Exposure to natural hazards Version 2.0: Flood hazard modeling». Taroudant polydisciplinary faculty of the Ibn Zohr University of Agadir, Morocco. ISBN: 978-9954-0-5393-5. 
12. United Nations International Strategy For Disaster Reduction (ISDR), Basic terms of disaster risk reduction at http://www.unisdr.org/eng/library/lib-terminology-eng\%20home.htm [Accessed Nov. 23, 2017]

13. A. T. Ngo (2014). Evaluation environnementale du risque d'inondation dans le delta du fleuve ha Thanh (centre Viêt-Nam). "Thèse en Géographie-Aménagement-Environnement ». Université d'Orléans, France, 429p. 